\title{
Seroprevalence of Toxoplasma gondii and Neospora caninum in red deer from Central Italy
}

\author{
Guido Rocchigiani', Simona Nardoni', Carlo D'Ascenzi', Sandro Nicoloso², Federico Picciolli², \\ Roberto Amerigo Papini' ${ }^{1}$, Francesca Mancianti ${ }^{1}$ \\ ${ }^{1}$ Dipartimento di Scienze Veterinarie, Università di Pisa \\ ${ }^{2}$ D.R.E.Am. Italia Soc. Coop. Agr. For. Via Garibaldi 3 - 52015 Pratovecchio (AR)
}

Rocchigiani G, Nardoni S, D'Ascenzi C, Nicoloso S, Picciolli F, Papini RA, Mancianti F. Seroprevalence of Toxoplasma gondii and Neospora caninum in red deer from Central Italy. Ann Agric Environ Med. 2016; 23(4): 699-701. doi: 10.5604/12321966.1226870

\begin{abstract}
Neospora caninum and Toxoplasma gondii are cosmopolite protozoan parasites impacting on human and animal health. In particular, T. gondii commonly infects human beings and all warm-blooded animals, while N. caninum is responsible for bovine abortion and neuromuscular disease in dogs. The aim of the presented survey was to evaluate the occurrence and prevalence of these parasites in the most numerous Italian red deer population. The sera of 60 red deer (Cervus elaphus) inhabiting Central Italy $\left(43^{\circ} 56^{\prime} \mathrm{N} 10^{\circ} 55^{\prime} \mathrm{E}\right)$ and killed by selective hunting were examined using an indirect fluorescent antibody test (IFAT) for both N. caninum and T. gondii antibodies. White blood cells (buffy coat) were also checked by PCR and T. gondii DNA was genotyped. Thirteen out of 60 sera (22\%) scored positive for Toxoplasma, 17 samples (28\%) were Neospora positive. Coinfection was recorded in 5 cases (8\%). T. gondii (genotype II) and N. caninum DNA was detected in one and 3 samples of buffy coat, respectively. The presented study is the first to examine the occurrence of these parasites in the most numerous red deer Italian population, confirming this animal species as carrier of the investigated pathogens. These animals spread near human settlements, co-inhabiting with final hosts of $T$. gondii and $N$. caninum and could contribute to their transmission to domestic ruminants and humans. In particular, the seroprevalence value for N. caninum was the highest among European records.
\end{abstract}

\section{- Key words \\ Cervus elaphus, tissue apicomplexa, IFAT, PCR, genotyping}

\section{INTRODUCTION}

The expansion of red deer (Cervus elaphus) in the last decades of the $20^{\text {th }}$ century, with a tenfold growth in abundance between 1970 - 1998, fits into a more general phenomenon of recovery experienced by the species in Europe in the same period [1]. In the Northern and Central Apennines the present occurrence of red deer is exclusively due to reintroduction. These wild ruminants have been consistently present in the province of Pistoia $\left(43^{\circ} 56^{\prime} \mathrm{N} 10^{\circ} 55^{\prime} \mathrm{E}\right)$ since at least 1995, with a gradual spread across these areas, and becoming the most abundant deer population in Central Italy. Hence, since 2000, the population has been the target of selective hunting, also in response to the increasing request for a careful planning of sustainable densities to minimize the impact of these populations on human activities [2]. These animals, in fact, show a high density near human settlements. The presence of red deer is especially proven $5 \mathrm{~km}$ from Pistoia city centre. For these reasons, they would be exposed to some parasite infection, transmitted by domestic carnivores, such as toxoplasmosis and neosporosis. The life cycle of the etiological agents involves cats and dogs as definitive hosts, respectively. Herbivores infection occurs by ingestion of oocysts on vegetation or in feed [3]. Infections with Toxoplasma gondii are widely prevalent in humans and animals worldwaide, especially food animals. Neospora caninum can cause neuromuscular disease in dogs and high rates of abortion in cattle [4], and the occurrence of specific

Address for correspondence: Simona Nardoni, Dipartimento di Scienze Veterinarie Università di Pisa, viale delle Piagge 2, 56124 Pisa

E-mail: simona.nardoni@unipi.it

Received: 21 April 2016; accepted: 16 June 2016 antibodies has been reported in healthy humans [5]. Such infections impact on human and animal health. In particular, T. gondii commonly infects many domesticated and wild animals used for food production and the European Food Safety Authority (EFSA) has recommended the surveillance and monitoring of toxoplasmosis in humans, animals and foodstuffs [6].

Data from literature on red deer from the Italian Alps report the occurrence of antibodies to $T$. gondii with prevalences from $0 \%[7]-40 \%$ [8] and to N. caninum in $2 \%$ [9]. Furthermore, other records from Europe refer to the seroprevalence of T. gondii in a $0 \%$ of animals from Belgium [3], 45\% in animals from the Czech Republic, Slovakia and Austria [10]. The reports about the occurrence of N. caninum in red deer in Europe refer 0\% from Belgium [3], 6\% from Czech Republic [10], 12\% from Spain [11] and 13\% from Poland [12].

However, to the best of our knowledge, there are no data about the presence of such infections in the population of $C$. elaphus from Central Italy. Therefore, the aim of the current study was to evaluate the occurrence of antibodies to T. gondii and N. caninum in red deer killed by selective hunting during the 2014-2015 hunting season.

\section{MATERIALS AND METHOD}

Blood samples were collected from the hearts of 60 red deer (43 females and 17 males), killed between January February 2015 during selective hunting, to which was added ethylenediaminetetraacetic acid (EDTA). Age classes were attributed by histology from the incisors and animals were 
grouped as yearlings (6-24 months old, 14 males and 13 females), sub-adult ( $2-4$ years old, 3 males) and adult $(>2$ years, 30 females). All the animals were shot in an area comprising the North-Eastern Pistoia province.

Plasma was used to perform indirect immunofluorescent antibody test (IFAT) and kept frozen at $-20^{\circ} \mathrm{C}$ until processed. IFAT for $T$. gondii was performed using 10 -well slides (ToxoSpot IF, BioMerieux Roma, Italy) and an antibovineIgG fluorescein isothiocyanate antibody produced in rabbit (Sigma-Aldrich, USA). Specimens were screened with a threshold dilution of 1:40 and positive samples were endtitrated using 2-fold dilution. Antibodies versus N. caninum were determined using 12-well slides (Fullerton Lab, Fullerton CA., USA). Plasma samples were screened with a threshold dilution of 1:50 and positive samples were then end-titrated using 2-fold dilution [10]. Positive and negative reference sera were used.

DNA from white blood cells (buffy coat) was extracted for molecular studies using Blood /cultured cell genomic DNA extraction mini kit (Fisher molecular biology, USA), using $200 \mu \mathrm{l}$ of specimen, as recommended by the manufacturer. A nested PCR was performed, as described by Jones et al. [13], using the $\mathrm{B} 1$ gene as target. Genotypic characterization of T. gondii DNA was performed by PCR amplification of 12 genetic markers (SAG1, 3-SAG2, 5-SAG2, SAG2 new, SAG3, BTUB, GRA6, C22-8, C29-2, L358, PK1) [14].

PCR was carried out, as described by Müller et al. [15], using primers that amplify a $337 \mathrm{bp}$ fragment of the Nc 5 region.

\section{RESULTS AND DISCUSSION}

Thirteen of 60 sera (22\%) scored positive for anti - Toxoplasma antibodies, with titers ranging from 1:40 - 1:2560, while 17 samples $(28 \%)$ were N. caninum positive, with antibody titers ranging from 1:50 - 1:1600. Co-infection was recorded in 5 cases $(8 \%)$. Positive and negative animals seemed to be quite homogeneously spread in the sampled area.

T. gondii DNA (genotype II) was detected in one Toxoplasma serologically negative sample. Three of 60 samples were found to be N. caninum PCR positive. Among them, 2 specimens were from seropositive animals (titers 1:50 and 1:400), while the other was from a seronegative red deer (Tab. 1).

This study is the first report of T. gondii and N. caninum seroprevalence in red deer in Italy associated with molecular analysis aimed at demonstrating parasitic DNA. A molecular survey dealing with the detection of both parasites was carried out in red deer from Belgium [3] with no positive findings. In the presented study, buffy coat was employed to perform molecular examinations, since blood was the unique sample available.

The seroprevalence for T. gondii (22\%) is in agreement with European data, showing an intermediate value. The occurrence of antibody titers $\geq 100$ in 10/13 subjects, along with parasite DNA in the blood of a yearling male, would suggest a horizontal transmission pattern as hypothesized by Formenti et al., [8]. The authors are aware of the fact that blood is not the most sensitive specimen. Nevertheless, the occurrence of parasites' DNA in such a sample would be indicative of an active infection.

The striking finding was the high seroprevalence value versus N. caninum. This result is higher than in both Italian
Table 1. Gender, age class and parasitological data of positive red deer.

\begin{tabular}{|c|c|c|c|c|c|}
\hline Number & Gender & $\begin{array}{l}\text { Age } \\
\text { class }\end{array}$ & $\begin{array}{c}\text { Toxoplasma } \\
\text { gondii IFAT } \\
\text { titre }\end{array}$ & $\begin{array}{l}\text { Neospora } \\
\text { caninum } \\
\text { IFAT titre }\end{array}$ & PCR results \\
\hline 1 & female & Y & $1: 80$ & negative & negative \\
\hline 2 & female & $\mathrm{Y}$ & $1: 80$ & negative & negative \\
\hline 3 & female & A & 1:80 & negative & negative \\
\hline 4 & female & $\mathrm{Y}$ & negative & $1: 200$ & negative \\
\hline 5 & female & $\mathrm{Y}$ & $1: 2560$ & negative & negative \\
\hline 6 & female & A & 1:40 & 1:400 & negative \\
\hline 7 & male & Y & negative & 1:50 & negative \\
\hline 8 & male & Y & negative & negative & Toxoplasma gondii positive \\
\hline 9 & female & $\mathrm{Y}$ & 1:320 & negative & negative \\
\hline 10 & male & Y & negative & negative & negative \\
\hline 11 & female & $\mathrm{Y}$ & $1: 640$ & 1:200 & negative \\
\hline 12 & male & Y & 1:80 & 1:400 & negative \\
\hline 13 & female & A & 1:80 & 1:800 & negative \\
\hline 14 & female & Y & negative & 1:400 & Neospora caninum positive \\
\hline 15 & female & $\mathrm{Y}$ & $1: 40$ & negative & negative \\
\hline 16 & male & SA & negative & 1:50 & Neospora caninum positive \\
\hline 17 & female & A & negative & 1:200 & negative \\
\hline 18 & female & A & negative & 1:50 & negative \\
\hline 19 & male & Y & negative & $1: 200$ & negative \\
\hline 20 & female & Y & negative & negative & Neospora caninum positive \\
\hline 21 & male & Y & 1:80 & $1: 50$ & negative \\
\hline 22 & male & Y & 1:40 & negative & negative \\
\hline 23 & female & A & negative & $1: 400$ & negative \\
\hline 24 & male & SA & negative & 1:50 & negative \\
\hline 25 & female & $\mathrm{Y}$ & $1: 40$ & negative & negative \\
\hline 26 & male & SA & negative & 1:100 & negative \\
\hline 27 & female & A & negative & 1:800 & negative \\
\hline 28 & female & A & negative & $1: 1600$ & negative \\
\hline
\end{tabular}

$\mathrm{Y}$-yearling; $\mathrm{A}$ - adult; $\mathrm{SA}$ - sub-adult

and European records. High titers were also observed in this case, as well as the occurrence of 3 PCR positive animals.

Reservoir definitive hosts, both cats and dogs, are widely present in this area, in particular dogs for wild boar hunting. Furthermore, the Pistoiese Apennine region is densely frequented by several free-ranging dogs and cats cohabiting with 'Popolo degli Elfi' (Elfi -people), a large community movement (about 200 individuals in over 15 groups of families) who reject the consumer society and follow an alternative rural way of life, that occupy abandoned and isolated houses far from urban areas. The animals are not registered nor checked for health status, and feed mainly on live prey.

The results obtained in the current study reveal that $T$. gondii infection occurs in red deer in Central Italy, and the detection of T. gondii genotype II is in agreement with recent findings in small mammals from the Czech Republic [16]. These data suggest a potential risk for a growing group of consumers when meat is administered raw or undercooked, considering that genotype II is the main cause of human infections [17]. Compared with beef, in fact, venison is considered superior in nutrient composition, thus offering potential benefits for human consumption, and it received higher scores for most of the sensory attributes examined [18]. 
The presented results confirm red deer as the most important wild ruminant acting as intermediate host for $N$. caninum [4]. Furthermore, this species may be a carrier of pathogens, which can be transmitted to domestic ruminants and humans.

\section{Acknowledgements}

The authors express their thanks to D.R.E.Am. and the selective hunters for having made red deers' blood available.

\section{REFERENCES}

1. Holtmeier FK. Animals' influence on the landscape and ecological importance - 2015 Springer Dordrecht, Heidelberg, New York, London. p 335.

2. Mattioli S, Meneguz PG, Brugnoli A, Nicoloso S. Red deer in Italy: recent changes in range and numbers. Hystrix It J Mamm. 2001; 12: 27-35.

3. De Craeye S, Speybroeckb N, Ajzenbergd D, Dardé ML, Collinet F, Tavernier P, Van Gucht S, Dorny P, Dierick K. Toxoplasma gondii and Neospora caninum in wildlife: Common parasites in Belgian foxes and Cervidae? Vet Parasitol. 2011; 178: 64-69.

4. Dubey JP, Lindsay DS. Neosporosis, toxoplasmosis, and sarcocystosis in ruminants. Vet Clin North Am Food An Pract. 2006; 22: 645-671.

5. Tranas J, Heinzen RA, Weiss LM, McAllister MM. Serological evidence of human infection with the protozoan Neospora caninum. Clin Diagn Lab Immunol. 1999; 6: 765-767.

6. Witkowski L, Czopowicz M, Nagy DA, Potarniche AV, Aoanei MA, Imomov N, Mickiewicz M, Welz M. Szaluś-Jordanow O, Kaba J. Seroprevalence of Toxoplasma gondii in wild boars, red deer and roe deer in Poland. Parasite. 2015; 22: 17-20.

7. Ferroglio E, Bosio F, Trisciuoglio A, Zanet S. Toxoplasma gondii in sympatric wild herbivores and carnivores: epidemiology of infection in the Western Alps. Parasit Vectors. 2014; 7: 196.
8. Formenti F, Trogu T, Pedrotti L, Gaffuri A, Lanfranchi P, Ferrari N. Toxoplasma gondii infection in alpine red deer (Cervus elaphus): its spread and effects on fertility. PLoS ONE 2015, 10, DOI:10.1371/ journal.pone.0138472.

9. Ferroglio E, Rossi L. Prevalence of Neospora caninum antibodies in wild ruminants from the Italian Alps. Vet Rec. 2001; 148: 754-755.

10. Bartova E, Sedlak K, Pavlik I, Literak I. Prevalence of Neospora caninum and Toxoplasma gondii antibodies in wild ruminants from the countryside or captivity in the Czech Republic. J Parasitol. 2007; 93: 1216-1218.

11. Almería S, Vidal D, Ferrer D. Pabón M, Fernández-de-Mera MI, RuizFons F, Alzaga V, Marco I, Calvete C, Lavin S, Gortazar C, López-Gatius F, Dubey JP. Seroprevalence of Neospora caninum in non-carnivorous wildlife from Spain. Vet Parasitol. 2007; 19: 21-28.

12. Goździk K, Jakubek EB, Björkman C, Bień J, Moskwa B, Cabaj W. Seroprevalence of Neospora caninum in free living and farmed red deer (Cervus elaphus) in Poland. Pol J Vet Sci. 2010; 13: 117-120.

13. Jones CD, Okhravi N, Adamson P, Tasker S, Lightman S. Comparison of PCR detection methods for B1, P30, and 18S rDNA genes of T. gondii in aqueous humor. Ophthalmol Vis Sci. 2000; 41; 634-644.

14. Su C, Shwab EK, Zhou P, Zhu XQ, Dubey JP. Moving towards an integrated approach to molecular detection and identification of Toxoplasma gondii. Parasitology. 2010; 137: 1-11.

15. Müller N, Zimmermann V, Hentrich B, Gottstein B. Diagnosis of Neospora caninum and Toxoplasma gondii infection by PCR and DNA hybridization immunoassay. J Clin Microbiol. 1996; 34: 2850-2852.

16. Machačová T, Ajzenberg D, Žákovská A, Sedlák K, Bártová E. Toxoplasma gondii and Neospora caninum in wild small mammals: seroprevalence, DNA detection and genotyping. Vet Parasitol. 2016; 223: 88-90.

17. Ajzenberg D, Yera H, Marty H, Paris L, Dalle F, Menotti J, et al. Genotype of 88 Toxoplasma gondii isolates associated with toxoplasmosis in immunocompromised patients and correlation with clinical findings. J Infect Dis. 2009; 199: 1155-1167.

18. Bureš D, Bartoň L, Kotrba R, Hakl J. Quality attributes and composition of meat from red deer (Cervus elaphus), fallow deer (Dama dama) and Aberdeen Angus and Holstein cattle (Bos taurus). J Sci Food Agric. 2015; 95: 2299-2306. 